\title{
Cultivating Creativity in Adult Literacy Education Settings
}

Dominique T. Chlup, Inspiring the Creative Within ${ }^{\circledR}$, LLC

Few traits are as desirable as creativity. In fact, according to chief executives around the world, creativity is the most sought-after trait in leaders. Yet creativity is also one of the most elusive concepts (Csikszenthmihalyi, 1996). There is no shortage of definitions. Some define creativity as novelty, effectiveness, ethicality (e.g., Cropley, 2001). Others characterize creativity as a psychological trait that produces high quality, novel, useful work appropriate to an audience (e.g., Sternberg, Lubert, Kaufman, \& Pretz, 2005). Others argue creativity is a confluence of personality traits, alternative ways of thinking and knowing, and a mixture of social and environmental influences (e.g., Kerka, 1999).

Teaching for creativity has been an increasing area of focus in children's education but has largely been ignored within adult education. Jeffrey and Craft (2001) note the distinction between teaching creatively and teaching for creativity but go on to state that both aspects are important. Indeed, many argue that creativity is essential to human existence (e.g., Jeffrey \& Craft, 2001). With so many differing beliefs, the starting point for literacy education instructors who wish to cultivate creativity in their adult basic education, GED, or ESL classrooms is to first believe they can. In an era where the notion that schools "kill creativity" (Robinson, 2006) and society has suppressed the creative potential of adults by encouraging intellectual conformity (Sternberg, 2017), instructors need to provide opportunities and encouragement to make creativity a habit and attitude adults possess for life. This article is an attempt to share with educators what researchers have found regarding the hallmarks of creativity. It also provides a sampling of proven techniques and approaches instructors can use in educational settings to help adult learners unlock and develop their creativity.

\section{The Status of Creativity Research}

In 1949, when J. P. Guilford gave his seminal Presidential Address to the American Psychological Association, he made a bold declaration: it was time to make creativity the center of psychological research (Guildford, 1950). As a result, 20,000 papers and 21,000 books now exist on creativity (Kaufman \& Gregoire, 2015). Most of the published theories of creativity lie outside the field of education in the areas of the arts, engineering, business, and psychology (Patston, 2017).

During the 1950s, creativity largely became associated with divergent thinking - a thinking process that highlights the ability to come up with many potential answers or solutions as opposed 
to convergent thinking - arriving at one correct answer. Much of the creativity research has focused on children. Yet several adult educators have sought to promote creativity in adult education (Edelson, 1999; Esslinger, 2011; Galbraith \& Jones, 2003; Hickson \& Housley, 1997; Hoggan, Lones, 2000; Kerka, 1999; Knox, 2011; Simpson, \& Stuckey, 2009; Tsai, 2012, 2013a, 2013b). A growing number of adult educators have investigated the role of the arts in adult education (Armstrong, 2005; Butterwick \& Dawson, 2006; Clover, 2006; Clover \& Stalker 2007; Lawrence, 2005; Merriweather, 2011; Olson, 2005; Sullivan, 2005).

Overall, though, very few studies have focused specifically on adults and creativity (Butler, 1967; Haanstra, 1999; Nemec \& Sullivan-Soydan, 2009). In fact, Tsai (2013a) conducted a keyword search of adult education journals over a 20 -year period and discovered only 18 articles. He identified six topic areas within those articles: (a) creative expression for health (Bennetts, 2004; Cueva, Kuhnley, \& Cueva, 2012; Noble, 2005; Stuckey, 2009); (b) communication and creativity (Clover, 2006; Grace \& Wells, 2007); (c) creative learning (Clark, 2001); (d) creativity in lifelong learning (Dovey \& Muller, 2011; Su, 2009); (e) creative expression in transformative learning (Luckie, 2005); and (6) creativity in adult education (Beckett, 2001; Clover, 2003; Edelson, 1999; Edelson \& Malone, 1999; Haanstra, 1999; Walshok, 1999).

Furthermore, Tsai's (2013b) review of the topic "creativity in older adults in journals," an inquiry that looked at 30 years worth of journal articles revealed only seven articles (13\%) were from the field of adult education. Therefore, if we want to cultivate creativity in adult literacy education settings, it requires us to look both within and beyond the field of adult education. It requires us, like the very act of being creative, to engage in qualities of originality, curiosity, risk taking, and a willingness to accept the idea there is not always a single correct solution.

\section{Hallmarks of the Creative Mind: What Creative People Do Differently}

To consider how to promote creativity, it is useful to know what creative people do differently. Kaufman and Gregoire (2015) analyzed over 100 years of scientific research and extracted 10 common themes of what highly creative people do differently. Their exploration revealed a series of paradoxes. Creative minds engage in mindfulness and the mind wandering of daydreaming. Creative people are characterized by openness yet also sensitivity. Collaboration is valued yet so is solitude. Play is emphasized along with seriousness and turning adversity into advantage. Intuition rules and paradoxically so does reason. According to Kaufman and Gregoire (2015), creative people have messy minds and messy processes.

Kaufman \& Gregoire's (2015) review found several elements promote creativity. Encouraging risk taking and originality by giving people the autonomy to decide for themselves how they will learn and create is a key element for promoting creativity. Daydreaming, personal time for reflection, and methods to promote inner exploration were all elements found to nurture creativity. A third component that aids building creativity is helping people find and grow their unique purpose and identity by making activities meaningful and directly linked to their personal goals. To encourage creativity, it is beneficial to focus on confidence building to increase how individuals learn new information and cope with adversity. Making tasks more conducive to flow by engaging learners in appropriate levels of challenge and helping them to develop supportive and positive social relations were all seen as elements to cultivate creativity. 


\section{How to Cultivate Creativity}

How can literacy educators help their learners cultivate creativity in educational settings? What practices, habits, and strategies might help learners become more creative?

\section{Lean on proven enhancements for creativity.}

Knox (2011) advocates for learning activities that use methods from the following six enhancements of creativity: setting aside time for solitude, supporting learners by suspending frequent and unnecessary criticism, building on sufficient preparation, interacting and sharing experiences, encouraging divergence to explore unusual directions, and building public understanding of the reasons for creativity. These types of activities include: learning in groups, writing creatively, role-playing, problem-based learning, and oneminute papers (Nilson, 2010).

Ask for feedback. One of the quickest strategies instructors can use to encourage creativity are 1-minute papers. One-minute papers are writing prompts that solicit feedback and gauge students' interest, relevance, analysis, and conceptual connections. Examples of 1-minute prompts include: "What interesting questions remain unanswered about today's topic? What idea expressed in today's class affected or influenced your personal opinions, viewpoints, or values? What did we discuss in class today that connects with what you are learning or have learned in other courses?" (Cuseo, 2019). Underlying the 1-minute technique is the broader recognition that stopping at the beginning, middle, or end of the class to ask a fresh series of questions, often results in novel, transformative insights.

Conduct better brainstorming. One of the most cited creativity development techniques is brainstorming. However, many brainstorming sessions resemble wading through mud-an energy zapping, uninspired trek. Gregersen (2018) suggests focusing on questions not answers for breakthrough insights. Inspired by Palmer's (2017) work on making creative discoveries through open, honest inquiry, Gregersen developed a brainstorming process he calls a "question burst." In this exercise, set a timer for 4 minutes, aim to generate 15 questions, and do this for at least three rounds. All variety of questions are welcome. However, Gregersen found descriptive questions (e.g., What's working? What's not? Why?) better precede speculative ones (e.g., What if? What might be? Why not?).

Alternatively, instructors can engage their students in "brainswarming" (also called "brainwriting") whereby learners work initially in silence and write their contributions on sticky notes they place on the board. Brainswarming contributes to cultivating creativity by allowing people to work side-by-side to produce ideas faster. Working in silence means the most talkative in the group cannot dominate the session. Fear of judgment is reduced, and silence allows people to move between thinking, writing, moving, and reading others' contributions to build off one another's ideas, which can lead to more novel contributions (McCaffrey \& Pearson, 2019).

Focusing on generating new questions for a problem, rather than answers encourages dynamics that build creativity. For instance, unlike in traditional brainstorming, rather than engaging in convergent thinking and rushing to provide an answer, learners depart from their usual habits of thinking. Since people can only contribute questions, this recasts the problem in innovative ways and allows learners to have a sense of control. They are not trying to think up an answer rather they are thinking down questions, which allows them to push past myopic thinking, closure phenomenon, and blaze a new trail. 
Think differently. For instructors who have never used creativity training or creative learning exercises before, one way to get started is to take learners through an activity that shows the difference between convergent and divergent thinking. Renzulli (2017) outlines an example whereby instructors begin by asking a question that has one correct answer (e.g., Who was the first President of the United States?). Instructors can follow-up by asking, "Are there any other answers to this question?" After getting a consensus there are not, instructors continue by asking a question with divergent answers (e.g., What are all the ways you might have come to class tonight?). Renzulli recommends using a list of general questions such as those developed by Arnold (1962) to spur learners' creative thinking (e.g., Modification: What new twist can you make? Substitution: What can you use instead? Minification: Suppose you could change your size or shape. How then might you have gotten to class?).

Integrate the arts. Since some of the first scholars arguing for creativity in the classroom were arts educators, arts-based learning activities are another way to promote creativity and imagination. Merriweather (2011) recommends using Spoken Word, a poetry-based art form that through its use of engagement, imaginative learning, authenticity, and the practice of democratic ideals embodies key elements of adult education such as meaning-making, transformation, and critical reflection.

Riley (2016) advocates for arts integration in adult math education classes (GED and ESL) to enhance creativity. For example, to encompass a math standard such as "add and subtract within 20 " and the art standard "use observation and investigation to make a work of art," instructors might have learners create buildings with the same number of total rooms, yet different sizes and configurations.

We tend to believe that original thinking is rare. However, all of these techniques demonstrate learners are capable of being true innovators. Educators can set learners up for success by building a culture of creativity. Cultivating creativity begins with not only the ability to learn and memorize and arrive at correct answers (convergent thinking) but also the ability to move beyond habitual ways of thinking and knowing to imagine potentialities and possibilities that expand beyond what has been dreamed of before (divergent thinking). But it does not end there. To maintain a culture of creativity, educators need to keep fighting the pressures against it. For creativity to flourish, learners must feel encouraged to take grand risks, pitch their wildest ideas, and champion ways that show nothing is impossible for even the word says, "I'm possible." This is literally the kind of thinking that has enabled people to change the world. It is the type of thinking that will enable learners to change their world. 


\section{References}

Armstrong, K. (2005). Autophotography in adult education: Building creative communities for social justice and democratic education. New Directions in Continuing Education, 107, 33-44. San Francisco, CA: Jossey-Bass.

Arnold, J. E. (1962). Useful creative techniques. In S. J. Parnes and H. F. Harding (Eds.). A source book for creative thinking (pp. 63-105). New York, NY: Charles Scribner's Sons.

Beckett, D. (2001). Hot action at work: A different understanding of "understanding." New Directions for Adult and Continuing Education, 92, 73-84.

Bennetts, C. (2004). The flight of the phoenix: Using hermeneutics to interpret the role of the mentor in the creative cycle. International Journal of Lifelong Education, 23(4), 367-383.

Butler, R. N. (1967). The destiny of creativity in later life. In S. Levin \& R. J. Khana (Eds.). Psychodynamic Studies on Aging: Creativity, reminiscing and dying (pp. 20-63). New York, NY: International Universities Press.

Butterwick, S. \& Dawson, J. (2006). Adult education and the arts. In T. Fenwick, T. Nesbit, and B. Spencer (Eds.). Contexts of adult education: Canadian perspectives (pp. 281-291). Toronto, Canada: Thompson Educational Publishing.

Clark, M. C. (2001). Off the beaten path: Some creative approaches to adult learning. New Directions for Adult and Continuing Education, 89, 83-92.

Clover, D. E. (2003). Environmental adult education: Critique and creativity in a globalizing world. New Directions for Adult and Continuing Education, 99, 5-15.

Clover, D. E. (2006). Culture and antiracism in adult education: An exploration of the contributions of artsbased learning. Adult Education Quarterly, 57(1), 46-61.

Clover, D. E. \& Stalker, J. (Eds.). (2007). The arts and social justice: Re-crafting adult education and community cultural leadership. Leicester, UK: NIACE.

Cropley, A. J. (2001). Creativity in education and learning: A guide for teachers and educators. London, England: Kogan Page Limited.
Cuseo, J. (2019) One-minute paper. Retrieved from http:// oncourseworkshop.com/self-awareness/one-minute-paper/

Cueva, M., Kuhnley, R., \& Cueva, K. (2012). Enhancing cancer education through the arts: building connections with Alaska Native people, cultures and communities. International Journal of Lifelong Education, 31(3), 341-357.

Csikszentmihalyi, M. (1996). Creativity: Flow and the psychology of discovery and invention. New York, NY: HarperCollins.

Dovey, K., \& Muller, L. (2011). Dangerous learning in edgy contexts: Creativity and innovation in the South African arts domain. International Journal of Lifelong Education, 30(5), 613-629.

Edelson, P. (1999). Creativity and adult education. New Directions for Adult \& Continuing Education, 81, 3-13.

Edelson, P. \& Malone, P. L. (1999). New vistas for adult education. New Directions for Adult \& Continuing Education, 81, 87-89.

Esslinger, D. S. (2011). Encouraging women's creative confidence: A case study of women's insights into their own creativity (unpublished doctoral dissertation). Capella University, Minneapolis, MN.

Gailbraith, M. W. \& Jones, J. D. (2003). Promotion and benefits of enhancing creativity in higher and adult education. Journal of Adult Education, 32(1), 18-28.

Grace, A. P., \& Wells, K. (2007). Using Freirean pedagogy of just ire to inform critical social learning in arts-informed community education for sexual minorities. Adult Education Quarterly, 57(2), 95-114.

Gregersen, H. (2019). Better brainstorming. Harvard Business Review OnPoint, 38-44.

Guildford, J. P. (1950). Creativity. American Psychologist, $5,444-454$.

Haanstra, F. H. (1999). The Dutch experiment in developing adult creativity. New Directions for Adult and Continuing Education, 81, 37-45. 
Hickson, J. \& Housley, W. (1997). Creativity in later life. Educational Gerontology, 23(6), 539-547.

Hoggan, C., Simpson, S., \& Stuckey, H. (Eds.). (2009). Creative expression in transformative learning: Tools and techniques for educators of adults. Malabar, FL: Krieger Publishing Company.

Jeffrey, R. \& Craft, A. (2001). The universalization of creativity. In A. Craft, R. Jeffrey, \& M. Leibling (Eds.). Creativity in education (pp. 1-16). London, England: Continuum.

Kaufman, S. B., and Gregoire, C. (2015). Wired to create: Unraveling the mysteries of the creative mind. New York, NY: Perigee Books.

Kerka, S. (1999). Creativity in adulthood. Eric Digest, No. 204. Retrieved from ERIC database (EDOCE99204).

Knox, A. (2011). Creativity and learning. Journal of Adult and Continuing Education, 17(2), 96-111.

Lawrence, R. L. (2005). Knowledge construction as contested terrain: Adult learning through artistic expression. New Directions for Adult and Continuing Education, 107, 3-11.

Lones, P. S. (2000). Learning as creativity: Implications for adult learners. Adult Learning, 11(4), 9-12.

Luckie, J. A. C. (2005). Life Journeys: Awakenings and learning Experiences. New Directions for Adult and Continuing Education, 108, 69-78.

McCaffrey, T. \& Pearson, J. (2019). Find innovation where you least expect it. Harvard Business Review OnPoint, $17-23$.

Merriweather, L. R. (2011). The Spoken Word as arts-based adult education. Journal of Adult and Continuing Education, 17(2), 51-63.

Nemec, P. B., \& Sullivan-Soydan, A. (2009). Teaching flexibility and creativity through student project development. Psychiatric Rehabilitation Journal, 32(4), 319-322.

Nilson, L. B. (2010). Teaching at its best: A researchbased resource for college instructors (3rd ed.). San Francisco, CA: Jossey-Bass.
Noble, S. E. (2005). Mental illness through popular theater: Performing (in) sanely. New Directions for Adult and Continuing Education, 107, 45-53.

Olson, K. (2005). Music for community education and emancipatory learning. New Directions for Adult and Continuing Education, 107, 55-64.

Palmer, P. J. (2017). The courage to teach: Exploring the inner landscape of a teacher's life. San Francisco, CA: John Wiley \& Sons.

Patson, X (2017). What I used to think about creativity in schools. In R. A. Beghetto \& J. C. Kaufman (Eds.). Nurturing creativity in the classroom (pp. 17-19). New York, NY: Cambridge University Press.

Renzulli, J. (2017). Developing creativity across all areas of the curriculum. In R. A. Beghetto \& J. C. Kaufman (Eds.). Nurturing creativity in the classroom (pp. 1719). New York, NY: Cambridge University Press.

Riley, S. (2016). Educator effectiveness webinar series enhancing the instructional program with creative arts Q\&A. Retrieved from https://files.eric.ed.gov/fulltext/ ED571602.pdf

Robinson, K. (2006, February). Do schools kill creativity? [Video file]. Retrieved from https://www. ted.com/talks/ken_robinson_says_schools_kill_ creativity?language $=\mathrm{en}$

Sternberg, R. J., Lubert, T. I., Kaufman, J. C., \& Pretz, J. E. (2005). Creativity. In K. J. Holyoak \& R. G. Morrison (Eds.). The Cambridge handbook of thinking and reasoning (pp. 351-369). New York, NY: Cambridge University Press.

Sternberg, R. J. (2017). Teaching for creativity. In R. A. Beghetto \& J. C. Kaufman (Eds.). Nurturing creativity in the classroom (pp. 355-380). New York, NY: Cambridge University Press.

Stuckey, H. L. (2009). Creative expression as a way of knowing in diabetes adult health education: An action research study. Adult Education Quarterly, 60(1), 46-64.

Su, Y. H. (2009). Idea creation: The need to develop creativity in lifelong learning practices. International Journal of Lifelong Education, 28(6), 705-717. 
Sullivan, A. M. (2005). Lessons from the Anhinga trail: Poetry and teaching. New Directions for Adult and Continuing Education, 107, 23-32.

Tsai, K. C. (2012). The value of teaching creativity in adult education. International Journal of Higher Education, $1(2), 84-91$.

Tsai, K. C. (2013a). Facilitating creativity in adult learners. (Doctoral dissertation). Retrieved from ProQuest (3617980).
Tsai, K. C. (2013b). A review of the inquiry of creativity in older adults in journals. British Journal of Education, 1(2), 20-28.

Walshok, M. L. (1999). Dialogue and collaboration as keys to building innovative educational initiatives in a knowledge-based economy. New Directions for Adult \& Continuing Education, 81, 77-86. 